\title{
Études/Inuit/Studies
}

\section{SALADIN D'ANGLURE, Bernard, 2006 Être et renaître inuit: homme, fermme ou chamane, Paris, Gallimard, 429 pages.}

\section{Christopher G. Trott}

Volume 30, numéro 2, 2006

L'influence de Marcel Mauss

The influence of Marcel Mauss

URI : https://id.erudit.org/iderudit/017577ar

DOI : https://doi.org/10.7202/017577ar

Aller au sommaire du numéro

\section{Éditeur(s)}

Association Inuksiutiit Katimajiit Inc.

Centre interuniversitaire d'études et de recherches autochtones (CIÉRA)

\section{ISSN}

0701-1008 (imprimé)

1708-5268 (numérique)

Découvrir la revue

Citer ce compte rendu

Trott, C. G. (2006). Compte rendu de [SALADIN D’ANGLURE, Bernard, 2006 Ettre et renaître inuit: homme, femme ou chamane, Paris, Gallimard, 429 pages.]

Études/Inuit/Studies, 30(2), 230-233. https://doi.org/10.7202/017577ar d'utilisation que vous pouvez consulter en ligne.

https://apropos.erudit.org/fr/usagers/politique-dutilisation/ 
Les cinq documents placés dans les annexes sont utiles mais un peu répétitifs. Les transcriptions complètes des entrevues (annexes 1 et 3) permettent évidemment de mieux situer les passages sélectionnés par l'auteur de même qu'elles restituent un peu la dynamique des échanges. L'annexe 2 fournit quelques renseignements supplémentaires sur le voyage à King William Island. L'annexe 4 offre la liste détaillée des questions posées mais celles-ci figurent déjà dans les annexes 1 et 3 . Quant à la liste des toponymes, elle recoupe les informations données dans les cartes.

En somme, ce petit ouvrage comporte des détails très riches sur divers aspects de la chasse et des savoirs inuit relatifs à l'ours polaire mais on est un peu déçu de ne pas en apprendre davantage, en particulier sur le plan de la symbolique. À cet égard, il me semble très dommage que l'auteur n'ait pas utilisé les travaux réalisés ailleurs par d'autres chercheurs qui se sont pourtant intéressés de très près à l'ours polaire. Pour en rester à l'Arctique central, ni les recherches de Vladimir Randa ni celles de Bernard Saladin d'Anglure, par exemple, ne sont mentionnées. Ces recherches auraient pourtant pu aider l'auteur à suivre quelques pistes supplémentaires et servir aussi ses futurs lecteurs soucieux d'en savoir plus. Mais ces références n'apparaissant même pas dans la section "Further Readings". Sur la forme, on regrettera la mauvaise qualité des cartes dont les toponymes demeurent souvent difficiles à déchiffrer. Bien qu'on puisse comprendre la difficulté d'une telle opération, l'absence d'une traduction complète du livre en inuktitut m'apparaît tout aussi regrettable. Une option alternative aurait été de vendre l'ouvrage avec un cd comportant les témoignages oraux en langue inuit, une manière de souligner au moins la place essentielle qu'occupe toujours la langue dans la culture.

Frédéric Laugrand CIÉRA

Université Laval

Pavillon De Koninck Québec (Québec), GlK 7P4

Canada

Frederic.Laugrand@ant.ulaval.ca

SALADIN D'ANGLURE, Bernard

2006 Etre et renaitre inuit: homme, femme ou chamane, Paris, Gallimard, 429 pages.

For those who have followed Bernard Saladin d'Anglure's (BSA) distinguished career in Inuit studies, this book is the long awaited magnum opus that brings together in one place his many writings, ideas and theories that have emerged over the ycars. In addition, this text provides the systematic exposition of his collaboration with Iqallijuq, Ujarak, and Kupaaq of Igloolik. The book is essentially a careful structural analysis of a large body of Inuit mythical (and other) texts through close reading of each of the segments of the stories and grounding them in other ethnographic materials. 
Igloolik has proved to be a rich ground for the compilation of "classic" Inuit texts ever since Rasmussen $(1929,1930)$ conducted his work there in 1921. BSA's collection of stories, for the most part from the extraordinarily competent Kupaaq, provides a third major collection of stories from Igloolik including those provided by John MacDonald (1998). For the comparative scholar, three sets of texts from one region over a 60 year period is an invaluable source of data. BSA's careful and extensive scholarship provides comparisons to both Rasmussen's and MacDonald's texts as well as with other Eastern Arctic collections such as those by Boas and his own work from Nunavik.

What is remarkable about many of the texts is how similar they are across time, providing virtually the same details in the major stories well known from the entire Inuit area. On the other hand, there are a number of important stories here that are much more detailed and carefully elaborated than the earlier versions available to scholars. In particular, the Arnaqtaaqtuq story is presented here in a much longer version than previously recorded allowing for more careful and extensive analysis. BSA also presents a long and elaborate version of the Itijjuaq story which has not previously appeared in many collections - a fact that BSA attributes to the Victorian sensibilities of the earlier collectors.

Initially, I found it annoying that BSA set out the Inuit texts in small sections, interspersing his analysis and commentary between each of these paragraphs. I had wanted to get the full richness of the story before moving on to the commentary. However, especially in the longer accounts, I came to realise that the placing of the commentary enriched my further reading of the text, having provided the necessary clues to move on to the next section. In his earlier work, BSA had usually provided the entire text and then his complex, interwoven commentary continually referring back to the text itself. While this neatly brought together the analysis he was trying to advance, it often made it difficult to follow with too many interconnections between the text and other ethnographic materials for the reader to keep track of. The exposition in Etre et renaitre Inuit is by far the clearest that I have seen and most useful in keeping track of the complex relationships among the texts and the ethnographic material.

The real strength of the book is the dialogues between BSA, Iqallijuq and Ujarak that provide insights into many of the stories provided by Kupaaq. Indeed, by the end of Chapter 4, on the Sun and the Moon story, this dialogue reaches a three-way commentary on the story almost equally divided among the three expositors. Where anthropologists have been criticised for placing their own analyses over indigenous explanations of the same story, BSA's technique here puts Iqallijuq's and Ujarak's comments on the same plane as his own, providing one of the first Inuit commentaries on their own texts.

The corpus of materials in this book derives primarily from Igloolik with one notable exception. Chapter 12 deals with a St. Lawrence Island text about a thirdgendered man who gives birth to a whale. BSA makes it absolutely clear that this text is included because it provides the structural inversion of the Ittijjuaq story in the previous chapter-the one major point in the book where the structural methods of 
analysis overdetermine the material BSA has chosen to include. While analytically I can appreciate the inclusion of the story, its incongruity in terms of the rest of the material from Igloolik is striking.

It is always very difficult to decide what order should be used to present a collection of texts like this and what analytical prerequisites should direct the order. Overall, BSA constructs a chronological sequence of the stories from the emergence of humans from the earth, through the increasing differentiation of the cosmos by the actions of each of the main mythological characters. While such an order is intellectually very satisfying, it remains an open question as to whether Inuit would ever order the stories in such a fashion. The determinants of structural analysis override the fact that the stories are often told in partial and fragmentary ways, in an ad hoc fashion, that means that few Inuit would ever experience the telling of these stories in such a systematic fashion. The pragmatics of such story telling are lost in this type of analysis, and perhaps new avenues of analysis need to be opened that would allow one to account for the indeterminate character of the data.

In the last two chapters of the book BSA opens up Igloolik story telling to move away from the "traditional" "myths" towards other forms of stories. He deals with the Atanarjuat story, a mythical account that takes on historical dimensions and the Ataguttaaluk story, an historical account that takes on mythical proportions. The transformative movements of both of these stories (in inverse directions) are developed through Zacharias Kunuk's film version of Atanarjuat as well as the various accounts, especially Iqallijuq's, of the Ataguttaaluk story. The careful analysis shows that the same myth-making properties of the classical stories are still at play, and that the accounts remain overdetermined by a wider cosmological order that continues to inject meanings into history.

This is a very important book that every scholar in the field of Inuit studies should work through to see the implications for their own work. In the same way that Rasmussen's ethnographic accounts have become the foundational data for so much research, BSA's work will become the foundation for future reflection on Inuit cosmology and symbolism. To date, Rasmussen's accounts have remained above the critical deconstruction that anthropology has applied to other early ethnographies (work that desperately needs to be done). I doubt that BSA's book will receive such intellectual immunity, but the debates that surely will follow from this text will stimulate new avenues of research in all areas.

\section{References}

MacDONALD, John

1998 The Arctic Sky: Inuit Astronomy, Star Lore, and Legends, Toronto, Royal Ontario Museum and Nunavut Research Institute. 
RASMUSSEN, Knud

1929 Intellectual Culture of the Iglulik Eskimos, Copenhagen, Gyldendalske Boghandel, Nordisk Forlag, Report of the Fifth Thule Expedition, 1921-24, $7(1)$.

1930 Iglulik and Caribou Texts, Copenhagen, Gyldendalske Boghandel, Nordisk Forlag, Report of the Fifth Thule Expedition, 1921-24, 7(2-3).

Christopher G. Trott

Native Studies Department

St. John's College, University of Manitoba

92 Dysart Road

Winnipeg, MB, R3T $2 \mathrm{M} 5$

trottcg@ec.umanitoba.ca

\section{STERN, Pamela and Lisa STEVENSON (eds)}

2006 Critical Inuil Studies. An Anthology of Contemporary Arctic Ethnography, Lincoln and London, University of Nebraska Press, 302 pages.

This book stems from a session held at the American Anthropological Association meetings in 2001. As stated in Lisa Stevenson's Introduction, its principal objective, is to show various ways of understanding Inuit society, as seen through the eyes of various anthropologists whose common characteristic is to make use of an ethnographic method. The editors were drawn by a desire to reintroduce American anthropology to Inuit Studies and to the Inuit in general.

The book is divided into 15 chapters (written by a total of 16 authors) distributed into three parts. Part 1 deals with "Figuring method." 'Texts by Molly Lee, Carol Zane Jolles, Michael J. Kral and Lori Idlout, Murielle Nagy, and Edmund (Ned) Searles describe various cultures of research in Inuit Studies. Through various examples, they show that social and political changes in academy, as well as in the communities, have contributed to new ways of conducting research. The central conclusion of the chapters is that research must be collaborative, but that it is not always easy to find out how this collaboration can be implemented.

Part 2 of the book is titled: "Reconfiguring Categories: Culture." With chapters by Pamela Stern, Nancy Wachowich, Nelson Graburn, Peter Kulchyski and Lisa Stevenson, it aims at explaining how culture, here defined as a form of practice, has been reworked for political and ethical ends by researchers and Inuit alike. Part 2 shows that far from being neutral, Inuit studies are influenced by and have had an influence on the social and cultural conditions of people involved in them. Among all three sections, Part 2 is the one that justifies the most the "Critical" component of the book's title.

Finally, Part 3 ("Reconfiguring Categories: Place") includes texts by Béatrice Collignon, Nobuhiro Kishigami, Ludger Müller-Wille and Linna Weber Müller-Wille, 